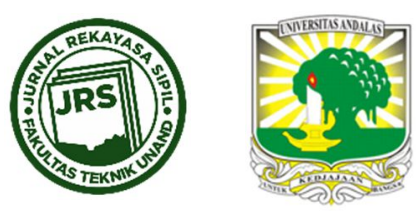

\title{
PENGARUH PENGGUNAAN SEMEN DAN FLY ASH TERHADAP NILAI CBR TANAH LEMPUNG MUARA FAJAR
}

\author{
SOEWIGNJO AGUS NUGROHO ${ }^{{ }^{*}}$, SYAWAL SATIBI ${ }^{1}$, RAFLYATULLAH ${ }^{2}$ \\ ${ }^{1}$ Prodi S1 Teknik Sipil, Fakultas Teknik, Universitas Riau. Pekanbaru, Indonesia \\ ${ }^{2}$ Prodi Magister Teknik Sipil, Fakultas Teknik, Universitas Riau. Pekanbaru, Indonesia \\ *Corresponding author: $ه$ nugroho.sa@eng.unri.ac.id
}

Naskah diterima : 11 November 2020. Disetujui: 24 Desember 2021

\begin{abstract}
ABSTRAK
Tanah merupakan bagian terpenting dari struktur bawah bangunan maupun perkerasan jalan. Tanah berfungsi memikul beban struktur atas, baik itu berupa beban statis maupun dinamis. Pembangunan jalan bebas hambatan (tol) khususnya di Riau, sebagian besar trace jalan melewati daerah dengan deposit tanah lempung lunak. Masalah pokok pada tanah lempung ialah kembang susut yang besar serta daya dukung yang rendah. Stabilisasi kimiawi dengan bahan tambah (additive) diperlukan untuk memperbaiki sifat-sifat tanah tersebut agar bisa digunakan sebagai lapis fondasi atau tanah dasar pada perkerasan jalan. Pencampuran semen dan abu terbang, sebagai additive, merupakan upaya perbaikan tanah. Penelitian ini bertujuan untuk melihat pengaruh pemakaian campuran abu terbang dan semen pada lempung Muara Fajar. Muara Fajar merupakan Desa di Kecamatan Rumbai, Kota Pekanbaru yang deposit tanah berupa lempung plastisitas tinggi, satu daerah yang akan dilewati jalan tol. Penelitian meliputi perubahan plastisitas karena penambahan additive, perubahan kadar air dan berat volume serta perubahan nilai CBR. Pengujian CBR difokuskan pada kondisi pemeraman 7 hari dan perendaman 4 hari, sesuai standar. Kadar semen dipilih 3\% dan $5 \%$ dengan masing-masing dicampur dengan abu terbang sebesar $5 \%, 10 \%$, dan $15 \%$. Hasil penelitian menunjukan, penambahan additive menurunkan sifat kembang susut. Perubahan kadar air dan berat volume mulai dari pencampuran sampai dengan perendaman tidak melebihi $20 \%$. penambahan additive meningkatkan kepadatan tanah. Nilai CBR pada kandungan $3 \%$ semen tidak bisa digunakan sebagai material tanah dasar. Nilai CBR, untuk kadar semen $5 \%$, dengan pemeraman 7 hari dan rendaman 4 hari, dengan kadar abu terbang $5 \%, 10 \%$, dan $15 \%$ berturut-turut sebesar $29,33 \%$; $31,47 \%$; dan $35,23 \%$. Penambahan $5 \%$ semen dan $5 \%$ pada tanah memenuhi syarat sebagai sub-base dan sub-grade jalan.
\end{abstract}

Kata kunci : Tanah Lempung, Fly ash, Semen, CBR

\section{PENDAHULUAN}

Salah satu pembangunan yang dilakukan di Riau adalah di bidang infrastruktur jalan tol. Permasalahan utama perkerasan jalan, jika melewati tanah lunak membutuhkan perbaikan tanah untuk memenuhi spesifikasi. Jika suatu jalan dibangun di atas tanah ekspansif, kerusakan yang dapat terjadi seperti retakan, subsidence, terangkatnya struktur pelat dan 
kerusakan jaringan pipa (Hartosukma, 2005). Perbaikan lempung lunak memerlukan upaya stabilisasi baik itu secara kimiawi maupun mekanis. Bahan aditif yang sering ditambahkan berupa semen, kapur, abu pembakaran batubara (pulverized coal) dan bahan pozzolanic lainnya. Bahan pozzolanic ini harus bersifat mengikat sehingga mampu meningkatkan kerapatan butiran tanah yang akhirnya mengalami perbaikan berat volume serta mengalami perbaikan besaran nilai daya dukung.

Dekade terakhir, abu terbang sebagai hasil pembakaran batubara, masuk kategori limbah B3. Peraturan Pemerintah (PP) Nomor 22 Tahun 2021 tentang Penyelenggaraan Perlindungan dan Pengelolaan Lingkungan Hidup, limbah batu bara dikeluarkan dari Kategori Berbahaya, Adapun limbah batu bara yang dikeluarkan dari kategori B3 adalah limbah yang bersumber dari proses pembakaran batu bara pada fasilitas Pembangkit Listrik Tenaga Uap (PLTU). Penjelasan Pasal 459 huruf C PP 22/2021 diatur fly ash hasil pembakaran batu bara dari PLTU dan kegiatan lainnya tak termasuk sebagai limbah B3, tetapi non-B3. Potensi pemanfaatan FA telah banyak diaplikasikan pada bidang geoteknik seperti stabilisasi tanah untuk jalan raya (Kolias et al, 2005); material urugan bekas penggalian, parit penambangan, serta dinding penahan (Wang \& Wu, 2006); landfill liners atau penutup (Cokca \& Yilmaz, 2004); dan sebagai bahan Geopolimer (Chindaprasirt et al., 2011). Pemanfaatan fly ash (FA) terbesar digunakan pada industri semen dan konstruksi beton sebesar 44,19\%; konstruksi perkerasan jalan dan tanggul sebesar 15,25\%; penimbunan daerah dataran rendah dan land filling sebesar 12,49\%; penimbunan bekas tambang (mine filling) sebesar 8,84\%;, pembuatan brick, masonry, dan tiles sebesar 7,61\%; bidang pertanian sebesar 2,47\%, dan untuk bidang-bidang lainnya 9,14\% (Loya \& Rawani, 2014).

Perbaikan nilai daya dukung pada stabilisasi semen dan/atau abu terbang ini dikarenakan adanya proses sementasi yang mampu meningkatkan daya ikat antar butiran, sehingga kemampuan saling mengunci antar butiran tinggi dan proses tersebut semakin meningkat seiring bertambahnya campuran semen dan fly ash. Selain itu, membuat rongga-rongga pori sampel yang telah ada sebagian akan dikelilingi bahan sementasi yang lebih keras, sehingga butiran tidak mudah berubah bentuk dan hancur (Husnah et al., 2019). Penambahan abu batubara dan semen pada tanah lempung juga dapat menurunkan nilai Indeks Plastisitas (IP). Penurunan tersebut seiring dengan bertambahnya persentase abu batubara dan semen. Penambahan abu batubara dan semen dapat meningkatkan nilai berat isi kering maksimum dan menurunkan nilai kadar air optimum, sehingga bisa meningkatkan nilai CBR pada stabilisasi campuran semen dan fly ash (Arifin, 2009).

Penggunaan semen, sampai kadar 20\%, untuk stabilisasi tanah lempung, telah terbukti meningkatkan kuat geser dan daya dukung tanah. Stabilisasi dengan penggunaan limbah fly ash ditambah semen melalui persentase campuran yang direncanakan, diharapkan bisa mengurangi kadar semen, memanfaatkan abu terbang sebagai pengganti semen, untuk memperbaiki sifat fisik maupun mekanis tanah lempung. Sehingga masalah lempung lunak dan permasalahan pencemaran lingkungan akibat penumpukan abu batubara dapat teratasi.

\subsection{Tanah Lempung}

Tanah terdiri dari agregat (butiran) mineral-mineral padat yang tidak tersementasi (terikat secara kimia) antara satu sama lain dari bahan-bahan organik yang telah melapuk (yang berpartikel padat) disertai dengan zat cair dan gas yang mengisi ruang-ruang kosong diantara partikel-partikel padat tersebut (Das et al., 1995). Tanah bisa bersifat non plastis (pasir, kerikil) atau plastis (lempung, lanau) tergantung dari ukuran butiran dan mineral penyusun. Tingkat plastisitas bergantung dari indek (Tabel 1). Lempung ekspansif 
merupakan lempung yang memiliki sifat khas yakni kandungan mineral ekspansif yang mempunyai kapasitas pertukaran ion tinggi, sehingga lempung ekspansif memiliki potensi kembang susut tinggi, apabila terjadi perubahan kadar air. Pada peningkatan kadar air, tanah ekspansif akan mengembang disertai dengan peningkatan tekanan air pori dan timbulnya tekanan kembang. Bila kadar air berkurang sampai batas susutnya, akan terjadi penyusutan. Sifat kembang susut yang demikian bisa menimbulkan kerusakan pada bangunan (Hardiyatmo, 2010). Hubungan antara batas susut, indek plastisitas dan potensi kembang susut lempung dapat dilihat pada Tabel 2.

Tabel 1. Hubungan Indek Plastisitas dan Jenis Tanah

\begin{tabular}{lll}
\hline Jenis Tanah & Indek Plastisitas & Tingkat Plastisitas \\
\hline Pasir & IP $=0$ & Tidak Plastis \\
\hline Lanau & $0<\mathrm{IP} \leq 7$ & Plastisitas Rendah \\
\hline Lempung Berlanau & $7<\mathrm{IP} \leq 17$ & Plastisitas Sedang \\
\hline lempung & IP $>17$ & Plastisitas Tinggi \\
\hline
\end{tabular}

Tabel 2. Hubungan batas susut dan indek plastisitas terhadap sifat kembang susut tanah

\begin{tabular}{|c|c|c|c|c|c|}
\hline $\begin{array}{l}\text { Batas Susut } \\
\text { Atterberg (\%) }\end{array}$ & $\begin{array}{l}\text { Susut } \\
(\%)\end{array}$ & Linier & $\begin{array}{l}\text { derajad } \\
\text { mengembang }\end{array}$ & $\begin{array}{l}\text { plasticity index } \\
(\%)\end{array}$ & $\begin{array}{l}\text { Swelling } \\
\text { potential }\end{array}$ \\
\hline$<10$ & $>8$ & & kritis & $0-15$ & low \\
\hline $10-12$ & $5-8$ & & sedang & $15-35$ & medium \\
\hline$>12$ & $0-5$ & & tidak kritis & $35-55$ & high \\
\hline & & & & $>55$ & very high \\
\hline
\end{tabular}

Sumber:(Chen, 2012)

Potensi peningkatan volume tanah lempung (mengembang, swelling) tergantung dari peningkatan kadar air, tekanan overburden, gradasi, maupun indeks plastisitas. Sedangkan penurunan volume tanah lempung (susut, shrinkage)) yang diakibatkan pengurangan kadar air mengakibatkan penyusutan yang cukup besar pada tanah ekspansif. Keadaan ini akan terjadi jika kadar air tanah menurun hingga mencapai batas yang lebih kecil dari nilai batas susutnya (Agung, 2014).

\subsection{Semen}

Semen sebagai bahan aditif untuk stabilisasi tanah banyak digunakan dalam berbagai penelitian (Damoerin, D. and Soepandji, 2001). Semen (Ordinary Portland Cement, OPC) adalah bahan hidrolis yang dihasilkan dengan cara menggiling bahan dasar terak (clinker) yang berupa kalsium silikat dan digiling bersama dengan bahan-bahan tambahan berupa satu atau lebih senyawa kalsium sulfate (bentuk kristal) dan bahan tambahan lain. Semen PCC (Portland Composite Cement) adalah material hasil penggilingan dengan clinker, gypsum, dan material pozzolan seperti, abu terbang, batu kapur, dan lainnya dengan satu atau lebih bahan-bahan anorganik lainnya. Semen mempunyai kemampuan mengeras dan mengikat antar butiran yang sangat berguna untuk memperoleh suatu masa tanah yang kokoh dan tahan terhadap deformasi (Soekoto, 1984). Variasi penambahan semen tersebut berkisar antara 6-35\% dari berat semen berdasarkan SNI 15-7064-2004. Semen PCC mengeluarkan panas hidrasi yang lebih rendah dibandingkan semen OPC. Sifat ini dibutuhkan untuk mengurangi panas hidrasi yang biasanya akan menimbulkan keretakan bagian dalam material. Adapun tahapan proses hidrasi pada campuran semen dengan tanah lempung (Arifin, 2009), yaitu :

- Sifat-sifat pada mineral lempung ini akan menyerap senyawa ion kalsium sehingga terjadi reaksi timbal balik antara keduanya. 
- Selanjutnya, pada partikel semen maupun partikel komposit ini akan terjadi proses kimiawi yang disebut pozzolan. Sedangkan kemampuan untuk mengikat antar komponen terbentuk oleh aluminium maupun partikel silikon. Hasil akhirnya ialah struktur lempung tersebut berubah menjadi agregat yang lebih padat.

Komposisi senyawa kimia dari semen PCC dapat dilihat dari Tabel 3.

Tabel 3. Komposisi Kimia Semen PCC (Susanto dkk, 2019)

\begin{tabular}{lccc}
\hline Komposisi & unit & \multicolumn{2}{c}{ Hasil } \\
\hline $\mathrm{Al}_{2} \mathrm{O}_{3}$ & $\%$ & 7,40 \\
\hline $\mathrm{CaO}$ & $\%$ & 57,38 \\
\hline $\mathrm{SiO}_{2}$ & $\%$ & 23,04 \\
\hline $\mathrm{Fe}_{2} \mathrm{O}_{3}$ & $\%$ & 3,36 \\
\hline Kehalusan & $\%$ & 2,00 \\
\hline Berat isi & $\mathrm{kg} /$ liter & 1,15 \\
\hline
\end{tabular}

\subsection{Fly Ash (Abu Terbang)}

Abu terbang (fly ash) bersama dengan abu dasar (bottom ash) merupakan hasil pembakaran batubara. Metode pembakaran batubara yang paling umum, terutama untuk produksi energi dalam skala besar, adalah pembakaran bahan bakar bubuk (pulverized coal), juga disebut sebagai pembakaran dengan suspensi. Pada proses ini batubara ditumbuk menjadi bubuk halus dan diinjeksi dengan aliran udara ke ruang tungku, sehingga menyala membentuk bola api pada suhu antara $1300^{\circ} \mathrm{C}-1700^{\circ} \mathrm{C}$. Sebagian besar tersebut dikenal sebagai Fly Ash (FA), sedangkan bottom ash (BA) adalah abu yang bercampur dengan fragmen hasil pembakaran lainnya, kemudian jatuh ke bagian bawah ruang pembakaran (Hower et al., 2017). FA tersusun oleh material yang bersifat heterogen yang umumnya berbentuk bulat dengan ukuran berkisar antara 0,5 $\mu \mathrm{m}-300 \mu \mathrm{m}$ (Chiang and Pan, 2017). FA tersusun oleh partikel-partikel serbuk halus yang sebagian besar berbentuk bola, baik padat atau berlubang, dan sebagian besar bersifat amorf. Abu Batubara memiliki spesific gravity sekitar 2,0 namun dapat bervariasi sebagian besar berkisar mulai dari 1,6 sampai dengan 3,1 (Pandian, 2013). Berdasarkan distribusi ukuran butirnya, FA tersusun oleh partikel berukuran butir pasir hingga lanau. FA memiliki luas permukaan yang tinggi dengan nilai bulk density yang rendah (Ram et al., 2014).

ASTM C 618-05 membagi 3 (tiga) kelas abu terbang berdasarkan kandungan senyawa kimia seperti ditunjukan dalam Tabel 4.

Tabel 4. Persyaratan Kandungan Kimia Abu Terbang (SNI 2460:2014)

\begin{tabular}{|c|c|c|c|c|c|c|c|}
\hline \multirow{2}{*}{ No } & \multirow{2}{*}{ Uraian } & \multicolumn{3}{|c|}{ ASTM C-618 } & \multicolumn{3}{|c|}{ ACI-226-ER part 1} \\
\hline & & $\mathbf{N}$ & $\mathbf{F}$ & $\mathbf{C}$ & $\mathbf{N}$ & $\mathbf{F}$ & $\mathbf{C}$ \\
\hline 1 & $\mathrm{SiO}_{2}+\mathrm{Al}_{2} \mathrm{O}_{3}+\mathrm{Fe}_{2} \mathrm{O}_{3}, \min , \%$ & 70 & 70 & 50 & - & 70 & 50 \\
\hline 2 & $\mathrm{CaO}, \mathrm{maks}, \%$ & - & - & - & - & $<10$ & $>10$ \\
\hline 3 & Sulfur Oxide $\left(\mathrm{SO}_{3}\right), \%$ & 4 & 5 & 5 & & 5 & 5 \\
\hline 4 & Sodium Dioxide $\left(\mathrm{Na}_{2} \mathrm{O}\right), \%$ & 1,5 & 1,5 & 1,5 & - & 1,5 & 1,5 \\
\hline 5 & Water Content, \% & 3 & 3 & 3 & - & 3 & 3 \\
\hline 6 & Hilang Pijar & & & & - & & \\
\hline 7 & Loss on Ignation (LoI), \% & 10 & 6 & 6 & - & 6 & 6 \\
\hline
\end{tabular}

Dari ketiga jenis fly ash tersebut yang dapat digunakan sebagai pengikat dalam campuran beton geopolimer jika fly ash memiliki kandungan $\mathrm{CaO}$ rendah dan kandungan $\mathrm{Si}$ dan $\mathrm{Al}$ lebih dari $50 \%$ karena kedua unsur tersebut yang berperan penting dalam proses 
polimerisasi. Adapun jenis fly ash yang baik digunakan adalah fly ash dari kelas $\mathrm{C}$ dan $\mathrm{F}$. (Kosnatha \& Utomo, 2007)

Penambahan fly ash akan memperkaya kandungan Alumina dan Silica pada tanah karena gradasi fly ash lebih besar dari tanah liat, maka penambahan fly ash juga akan membuat tanah lempung mempunyai gradasi yang lebih baik sehingga mudah diolah (Workability meningkat). Panas yang dihasilkan fly ash dapat mengurangi kadar air pada tanah basah. Tanah lempung dengan kandungan pozzolan yang sangat baik bereaksi dengan fly ash untuk membentuk suatu massa yang keras dan kaku (Hartosukma, 2005).

\subsection{Stabilisasi Tanah}

Stabilisasi tanah dibedakan menjadi 2 (dua) yaitu stabilisasi mekanis dan stabilisasi kimia. stabilisasi mekanis dilakukan dengan cara mengganti material atau mencampur 2 material atau lebih yang memenuhi spesifikasi. Stabilisasi kimiawi dilakukan dengan mencampurkan tanah dengan bahan tambah (additive) pada komposisi tertentu. Menurut Ilyas (Ilyas et al, 2008), stabilisasi sebenarnya adalah solidifikasi, yaitu penambahan zat aditif (baik dalam bentuk sebenarnya atau hanya terkandung dari suatu bahan) ke dalam suatu massa tanah untuk meningkatkan sifat mekanisnya. Stabilisasi dapat mengubah indeks properties (seperti kadar air, berat jenis, dan sebagainya), kekuatan, deformasi serta permeabilitas tanah (Forsman et al, 2015). Stabilisasi dengan bahan aditif dapat mengubah karakteristik fisik maupun kimia tanah asli menjadi lebih baik/stabil dan lebih tinggi daya dukungnya. Beberapa bahan stabilisasi (additive) yang biasa dipakai adalah semen, kapur, abu terbang, dan bahan berbasis senyawa hidro-karbon.

Stabilisasi dengan bahan tambah semen sudah dilakukan oleh beberapa peneliti seperti (Nugroho et al., 2021, 2017), Andriani (Andriani et al., 2012), Huri (Huri et al., 1989), Darmawan (Darmawan et al., 2018). Penggunaan semen sebagai aditif pada semua jenis tanah terbukti meningkatkan sifat fisik dan sifat mekanik tanah sampai kadar semen $20 \%$. Penggunaan semen $>20 \%$ tidak efektif bahkan berpotensi menurunkan kekuatan.

Pemanfaatan abu terbang sebagai aditif lempung plastisitas tinggi telah dilakukan Zulnasari (Zulnasari et al., 2021), (Deepak et al., 2020), Lembasi (Lembasi et al., 2021), Nugroho (Nugroho et al., 2020). penambahan abu terbang sampai dengan $30 \%$ berhasil menurunkan sifat kembang susut dan swelling, meningkatkan nilai CBR dan UCS dan bisa dimanfaatkan sebagai material perkerasan jalan.

\subsection{Pengujian CBR}

CBR merupakan perbandingan diantara beban eksperimen dengan beban standar yang ditetapkan dalam persentase. Pada umumnya metode perencanaan perkerasan jalan yang dipakai dan dapat dikenal adalah cara CBR. Dalam menentukan tebal lapis perkerasan dari nilai CBR dipakai grafik yang dikembangkan untuk berbagai macam muatan roda kendaraan melalui intensitas lalu lintas.

Pada uji Lab, tanah uji yang didapatkan baru berupa tanah asli, tanah timbun maupun tanah galian yang dipadatkan mencapai 95\% kepadatan maksimum. Sehingga bisa disimpulkan bahwa, kemampuan lapisan tanah yang mendukung beban sesudah tanah itu dipadatkan disebut dengan daya dukung tanah dasar. Pada pengujian CBR, terdapat beberapa pengukuran: 


$$
\begin{array}{ll}
C B R_{0,1^{\prime \prime}}=\frac{p_{1}}{13,50} \times 100 \% & \left(\mathrm{p}_{1} \text { dalam } \mathrm{kg} / \mathrm{cm}^{2}\right) \\
C B R_{0,2^{\prime \prime}}=\frac{p_{2}}{20,00} \times 100 \% & \left(\mathrm{p}_{2} \text { dalam } \mathrm{kg} / \mathrm{cm}^{2}\right)
\end{array}
$$

Kementerian Pekerjaan Umum dan Perumahan Rakyat (PUPR) mengeluarkan aturan tebal minimum perbaikan tanah dasar apabila nilai CBR tanah dasar tidak memenuhi persyaratan. PUPR memberi syarat nilai CBR minimum tanah dasar (sub-grade) untuk perkerasan jalan raya sebesar $6 \%$ (soaked). syarat tebal minimum perbaikan tanah dasar sebagai sub-grade dapat dilihat pada Tabel 5 .

Tabel 5. Standar tebal minimum perbaikan sub-grade Perkerasan Jalan

\begin{tabular}{lcccc}
\hline \multirow{2}{*}{$\begin{array}{c}\text { Kelas kekuatan sub- } \\
\text { grade }\end{array}$} & \multicolumn{2}{c}{ CBR (\%) sub-grade } & \multicolumn{2}{c}{ tebal minimum perbaikan tanah dasar } \\
\cline { 2 - 5 } & unsoked & soaked & flexible pavement & rigid pavement \\
\hline Sub-grade 6 (SG-6) & $\geq 12$ & $\geq 6$ & - & 300 \\
\hline Sub-grade 5 (SG-5) & & 5 & 100 & 300 \\
\hline Sub-grade 4 (SG-4) & & 4 & 150 & 300 \\
\hline Sub-grade 3 (SG-3) & & 3 & 200 & 300 \\
\hline Sub-grade 2,5(SG-2) & & 2,5 & 250 & 300 \\
\hline
\end{tabular}

Ingels dan Metcalf (Ingles and Metcal 1972) memberikan rekomendasi besar nilai kekuatan tanah yang di stabilisasi dengan semen sebagai lapis fondasi perkerasan jalan (Tabel 6)

Tabel 6. Syarat Stabilisasi tanah dengan semen sebagai material fondasi perkerasaan jalan

\begin{tabular}{|c|c|c|c|c|}
\hline \multirow{2}{*}{ Purpose } & \multicolumn{2}{|c|}{ UCS (curing 7 days) } & \multicolumn{2}{|c|}{ CBR (soaked 4 days) } \\
\hline & I-M $\mathbf{M}^{1)}$ & $\mathbf{S N I}^{2)}$ & I-M & SNI \\
\hline $\begin{array}{l}\text { road sub-base, formation backfill } \\
\text { for trenches }^{3)}\end{array}$ & $350-1050$ & 200 & $20-80$ & $20-40$ \\
\hline $\begin{array}{l}\text { road sub-base, base for light } \\
\text { traffict }^{3)}\end{array}$ & $700-1400$ & 600 & $50-150$ & $>80$ \\
\hline $\begin{array}{l}\text { base for heavy traffic, building } \\
\text { block }^{3)}\end{array}$ & $1400-5600$ & $2000-2400$ & $200-600$ & $100-200$ \\
\hline $\begin{array}{l}\text { embankment protection } \\
\text { floodway }{ }^{3)}\end{array}$ & $>5600$ & & $>600$ & \\
\hline $\begin{array}{l}\text { : I-M (Ingels and Metcalf, } 19 \\
\text { : SNI 03-3438-194 } \\
\text { : standard curing } 7 \text { days and }\end{array}$ & oaked 4 days & & & \\
\hline
\end{tabular}
raya

\section{METODOLOGI PENELITIAN}

\subsection{Persiapan Benda Uji}

Benda uji yang digunakan berupa tanah lempung terganggu yang diambil dari Muara Fajar, pada trace rencana jalan tol tujuan Pekanbaru-Dumai. Hasil pengujian kadar air asli lempung Muara Fajar diperoleh sebesar $43,80 \%$. Pengujian pendahuluan lainnya pada tanah asli, spesific gravity 2,71; batas cair (liquid limit) sebesar $69,59 \%$; batas plastis (plastic limit) nilainya $32,39 \%$; batas susut (shrinkage limit) besarnya $19,82 \%$; dan indek plastisitas (plasticity index) adalah 37,20. Menurut USCS (Unified Soil Classification System), lempung termasuk kategori lempung plastisitas tinggi (high plasticity clay, $\mathrm{CH}$ ) dengan sifat ekspansif. Pemadatan standard Proctor di laboratorium, didapatkan nilai kadar air optimum 
(Optimum Moisture Content, OMC) dan kepadatan kering maksimum (Maximum Dry Density, MDD) sebesar 32,25\% dan 13,82 kN/m2.

Abu terbang (fly ash) yang merupakan sisa pembakaran batubara dari Pembangkit Listrik Tenaga Uap (PLTU) Tenayan Raya, Pekanbaru. Pemeriksaan abu terbang dilakukan untuk pemeriksaan kandungan senyawa kimia dan tipe abu terbang. hasil pengujian abu terbang dari PLTU Tenayan Raya dapat dilihat pada Tabel 7.

Tabel 7. Kandungan kimia abu terbang PLTU Tenayan Raya

\begin{tabular}{lccc}
\hline Parameter & Rumus Kimia & unit & Hasil \\
\hline Silicon Dioxide $^{1)}$ & $\mathrm{SiO}_{3}$ & $\%$ & 59,25 \\
\hline Aluminum Trioxide $^{2)}$ & $\mathrm{Al}_{2} \mathrm{O}_{3}$ & $\%$ & 29,25 \\
\hline Iron Trioxide $^{3)}$ & $\mathrm{Fe}_{2} \mathrm{O}_{3}$ & $\%$ & 5,45 \\
\hline Titanium Dioxide & $\mathrm{TiO}_{2}$ & $\%$ & 0,83 \\
\hline Calcium Oxide $^{4)}$ & $\mathrm{CaO}$ & $\%$ & 1,54 \\
\hline Magnesium Oxide & $\mathrm{MgO}$ & $\%$ & 0,31 \\
\hline Potassium Oxide & $\mathrm{K}_{2} \mathrm{O}$ & $\%$ & 2,23 \\
\hline Sodium Oxide & $\mathrm{Na}_{2} \mathrm{O}$ & $\%$ & 0,68 \\
\hline Phosphorus Pentoxide & $\mathrm{P}_{2} \mathrm{O}_{5}$ & $\%$ & 0,04 \\
\hline Sulphur Trioxide & $\mathrm{SO}_{3}$ & $\%$ & 0,29 \\
\hline Manganese Dioxide & $\mathrm{MnO}_{2}$ & $\%$ & 0,01 \\
\hline Loss on Ignition & $\mathrm{LoI}$ & $\%$ & 18,89 \\
\hline
\end{tabular}

\subsection{Variasi Benda Uji}

Variasi benda uji terdiri dari tanah asli (TA) dan campuran lempung, semen, serta abu terbang. kandungan semen divariasikan menjadi 2 (dua), yaitu kadar semen 3\% (S3) dan kadar semen 5\% (S5). variasi kadar abu terbang terbagi menjadi 3 (tiga) yaitu 5\% (FA5), 10\% (FA10) dan 15\% (FA15). Perawatan sampel dibedakan menjadi tanpa pemeraman (C0) dan pemeraman selama 7 hari $(\mathrm{C} 7)$. untuk lebih jelas, variasi sampel dapat dilihat pada Tabel 8.

Tabel 8. Variasi Benda uji

\begin{tabular}{|c|c|c|c|c|c|c|c|}
\hline \multirow[t]{2}{*}{ Deskripsi Variasi Sampel } & \multicolumn{2}{|c|}{ semen $(\%)$} & \multicolumn{3}{|c|}{ Fly Ash (\%) } & \multicolumn{2}{|c|}{$\begin{array}{c}\text { curing } \\
\text { (day) }\end{array}$} \\
\hline & 3 & 5 & 5 & 10 & 15 & 0 & 7 \\
\hline Tanah Asli (TA 100\%) & - & - & - & - & - & $\sqrt{ }$ & - \\
\hline TA $92 \%+$ S3-FA5-Co & $\sqrt{ }$ & - & $\sqrt{ }$ & - & - & $\sqrt{ }$ & - \\
\hline TA $87 \%+$ S3-FA10-Co & $\sqrt{ }$ & - & - & $\sqrt{ }$ & - & $\sqrt{ }$ & - \\
\hline TA $82 \%+$ S3-FA15-Co & $\sqrt{ }$ & - & - & - & $\sqrt{ }$ & $\sqrt{ }$ & - \\
\hline TA $92 \%+$ S3-FA5-C7 & $\sqrt{ }$ & - & $\sqrt{ }$ & - & - & - & $\sqrt{ }$ \\
\hline TA 87\%+S3-FA10-C7 & $\sqrt{ }$ & - & - & $\sqrt{ }$ & - & - & $\sqrt{ }$ \\
\hline TA $82 \%+$ S3-FA15-C7 & $\sqrt{ }$ & - & - & - & $\sqrt{ }$ & - & $\sqrt{ }$ \\
\hline TA $90 \%+$ S5-FA5-Co & - & $\sqrt{ }$ & $\sqrt{ }$ & - & - & $\sqrt{ }$ & - \\
\hline TA $85 \%+$ S5-FA10-Co & - & $\sqrt{ }$ & - & $\sqrt{ }$ & - & $\sqrt{ }$ & - \\
\hline TA $80 \%+$ S5-FA15-Co & - & $\sqrt{ }$ & - & - & $\sqrt{ }$ & $\sqrt{ }$ & - \\
\hline TA $90 \%+$ S5-FA5-C7 & - & $\sqrt{ }$ & $\sqrt{ }$ & - & - & - & $\sqrt{ }$ \\
\hline TA $85 \%+$ S5-FA10-C7 & - & $\sqrt{ }$ & - & $\sqrt{ }$ & - & - & $\sqrt{ }$ \\
\hline TA $80 \%+$ S5-FA15-C7 & - & $\sqrt{ }$ & - & - & $\sqrt{ }$ & - & $\sqrt{ }$ \\
\hline
\end{tabular}

Pencampuran benda uji dilakukan dalam kondisi kering oven dengan perbandingan berat kering. Lempung dipisahkan dari butiran kerikil dibuang dari tanah lempung dengan cara dipisahkan menggunakan saringan no. 4. Abu terbang dipakai yang lolos saringan no. 200. Benda uji diaduk rata dengan menambah air 50\% dari berat total campuran. Pencetakan 
sampel uji CBR dilakukan dalam mold CBR dengan melakukan pemadatan standar Proctor pada kadar air $50 \%$. Pemeraman dilakukan selama 7 (tujuh) hari dengan cara menyimpan benda uji bersama mold dalam ruang tertutup dengan temperature terjaga pada suhu kamar.

\subsection{Pelaksanaan Pengujian}

Pengujian dilaksanakan di Laboratorium Mekanika Tanah dan Batuan Universitas Riau. Setiap variasi benda uji dilakukan pemeriksaan batas-batas Atterberg. Pengujian CBR dilakukan pada benda uji yang telah diperam (curing) selama 7 hari. Pengujian CBR dilakukan pada kondisi unsoaked (tanpa rendaman) dan soaked (rendaman). perubahan kadar air dan berat volume diukur pada waktu-waktu setelah dicampur, setelah dipadatkan (non-curing), setelah curing 7 hari, dan setelah direndam 4 hari.

\section{HASIL DAN PEMBAHASAN}

\subsection{Hasil Pengujian Properties Tanah}

Perubahan batas-batas Atterberg akibat penambahan semen dan abu terbang pada lempung asli dapat dilihat pada Tabel 9 .

Tabel 9. Nilai Batas-batas Atterberg pada variasi benda uji

\begin{tabular}{lllll}
\hline \multirow{2}{*}{ Diskripsi Variasi Sampel } & \multicolumn{2}{l}{ Atterberg Limits (\%) } & USCS \\
\cline { 2 - 5 } & $\begin{array}{l}\text { Liquid } \\
\text { limit }\end{array}$ & $\begin{array}{l}\text { Plastic } \\
\text { limit }\end{array}$ & $\begin{array}{l}\text { Plasticity } \\
\text { index }\end{array}$ & Classification \\
\hline Tanah Asli (TA) & 69,59 & 32,39 & 37,20 & $\mathrm{CH}$ \\
\hline TA 92\% + Semen 3\% + Abu terbang 5\% & 56,05 & 33,52 & 22,54 & $\mathrm{MH}$ \\
\hline TA 87\% + Semen 3\% + Abu terbang 10\% & 54,64 & 35,86 & 18,78 & $\mathrm{MH}$ \\
\hline TA 82\% + Semen 3\% + Abu terbang 15\% & 52,89 & 37,26 & 15,63 & $\mathrm{MH}$ \\
\hline TA 90\% + Semen 5\% + Abu terbang 5\% & 59,35 & 45,13 & 14,22 & $\mathrm{MH}$ \\
\hline TA 85\% + Semen 5\% + Abu terbang 10\% & 58,00 & 46,86 & 11,14 & $\mathrm{MH}$ \\
\hline TA 80\% + Semen 5\% + Abu terbang 15\% & 56,83 & 48,89 & 7,94 & $\mathrm{MH}$ \\
\hline
\end{tabular}

Merujuk pada Tabel 9, penambahan semen dan abu terbang mengakibatkan penurunan batas cair (liquid limit) dan meningkatnya batas plastis (plastic limit). turunnya batas cair dan naiknya batas plastik mengakibatkan turunnya indek plastisitas. Penambahan bahan aditif berupa semen dan kapur mengakibatkan perubahan batas-batas Atterberg dan merubah klasifikasi tanah sistem USCS dari lempung plastisitas tinggi (high plasticity clay, $\mathrm{CH}$ ) menjadi lanau plastisitas tinggi (high plasticity silt, $\mathrm{MH}$ )

\subsection{Hasil Pengujian CBR Curing 7 Hari}

Hasil pengujian CBR dengan campuran semen dan fly ash, seperti yang terlampir pada Tabel 10.

Tabel 10. Hasil pengujian CBR dengan campuran semen dan fly ash

\begin{tabular}{lllll}
\hline \multirow{2}{*}{ Diskripsi Variasi Sampel } & unsoaked & \multicolumn{3}{c}{ soaked 4 days } \\
\cline { 2 - 5 } & $\begin{array}{l}\text { unit } \\
\text { weight }\end{array}$ & CBR (\%) & $\begin{array}{l}\text { unit } \\
\text { weight }\end{array}$ & CBR (\%) \\
\hline Tanah Asli (TA) & 16,083 & 0,784 & 16,097 & 0,500 \\
\hline TA 92\% + Semen 3\% + Abu terbang 5\% & 18,379 & 3,372 & 18,391 & 1,25 \\
\hline TA 87\% + Semen 3\% + Abu terbang 10\% & 18,511 & 5,740 & 18,552 & 2,42 \\
\hline TA 82\% + Semen 3\% + Abu terbang 15\% & 19,733 & 8,318 & 19,754 & 5,72 \\
\hline
\end{tabular}




\begin{tabular}{lllll}
\hline \multirow{2}{*}{ Diskripsi Variasi Sampel } & unsoaked & \multicolumn{3}{c}{ soaked 4 days } \\
\cline { 2 - 5 } & $\begin{array}{l}\text { unit } \\
\text { weight }\end{array}$ & CBR (\%) & $\begin{array}{l}\text { unit } \\
\text { weight }\end{array}$ & CBR (\%) \\
\hline TA 90\% + Semen 5\% + Abu terbang 5\% & 19,512 & 36,819 & 19,521 & 29,33 \\
\hline TA 85\% + Semen 5\% + Abu terbang 10\% & 20,174 & 39,565 & 20,178 & 31,47 \\
\hline TA 80\% + Semen 5\% + Abu terbang 15\% & 20,542 & 42,862 & 20,654 & 35,23 \\
\hline
\end{tabular}

Berdasarkan Tabel 10, penambahan semen dan abu terbang akan meningkatkan berat volume tanah dan nilai CBR. Kepadatan tanah (berat volume kering) yang semakin tinggi, akan menghasilkan nilai CBR yang tinggi. Kepadatan tanah juga bergantung pada kandungan air. Pada berat volume sama, semakin tinggi kadar air, kepadatan tanah akan semakin kecil.

\subsection{Perubahan kadar air sampel selama pengujian}

Perubahan kandungan air awal, setelah dicampur, curing 7 hari dan perendaman 4 hari.

Tabel 11. Perubahan kadar air pada benda uji CBR

\begin{tabular}{lcccc}
\hline \multirow{2}{*}{ Diskripsi Variasi Sampel } & \multicolumn{2}{l}{ kadar air $(\%)$} & & \\
\cline { 2 - 5 } & awal & mixing & curing & soaked \\
\hline Tanah Asli (TA) & 50 & 50,00 & 48,55 & 59,55 \\
\hline TA 92\% + Semen 3\% + Abu terbang 5\% & 50 & 46,00 & 45,50 & 51,87 \\
\hline TA 87\% + Semen 3\% + Abu terbang 10\% & 50 & 45,65 & 43,50 & 49,59 \\
\hline TA 82\% + Semen 3\% + Abu terbang 15\% & 50 & 41,00 & 40,13 & 45,71 \\
\hline TA 90\% + Semen 5\% + Abu terbang 5\% & 50 & 45,00 & 39,99 & 45,20 \\
\hline TA 85\% + Semen 5\% + Abu terbang 10\% & 50 & 42,50 & 38,15 & 43,46 \\
\hline TA 80 $\%$ + Semen 5\% + Abu terbang 15\% & 50 & 40,00 & 37,11 & 42,26 \\
\hline
\end{tabular}

Sifat semen, jika bereaksi dengan air akan melepaskan energi (panas), sehingga penambahan semen dan/atau abu terbang akan menyerap air. Pencampuran benda uji dengan air akan menurunkan kandungan air campuran. Pada kandungan abu terbang sama (5\%), penambahan semen $3 \%$ menurunkan kadar air menjadi $46 \%$ sementara tambahan semen $5 \%$ menurunkan kadar air menjadi $45 \%$. pada kadar semen yang sama (5\%), penambahan abu terbang $10 \%$ dan $15 \%$ akan menurunkan kandungan air berturut-turut menjadi $42,50 \%$ dan $40 \%$. Semakin banyak semen dan/atau abu terbang yang ditambahkan dalam campuran, penyerapan air akan semakin besar.

Selama curing, reaksi antara tanah, semen, dan abu terbang terus berlangsung. Karena reaksi hidrasi membutuhkan air, selama curing terjadi penurunan kadar air. penurunan kandungan air terbesar terjadi pada kadar semen $5 \%$ dan abu terbang $5 \%$. Artinya semen lebih besar menyerap air daripada abu terbang.

Perendaman (soaked) 4 hari memberi kesempatan air untuk masuk ke dalam pori-pori tanah. kecepatan air masuk ke dalam pori-pori (rembesan) tergantung dari kepadatan tanah dan volume/ukuran pori-pori tanah. penambahan air selama perendaman terbesar terjadi pada benda uji dengan kandungan semen 3\% dan abu terbang 5\% (TA-S3-FA5-C7). Tambahan air terkecil selama perendaman terjadi pada kadar semen $5 \%$ dan abu terbang 15\% (TA-S5-FA15-C7). Dengan kata lain, penambahan semen 5\% dan abu terbang $15 \%$ memberikan nilai kepadatan tertinggi dan permeabilitas terendah. 


\subsection{Pengaruh Kepadatan dan CBR pada Campuran}

Meningkatnya harga CBR disebabkan oleh reaksi pozzolanic yang dihasilkan oleh semen dan fly ash yang mampu menaikan daya ikat antar partikel, sehingga kemampuan saling mengunci (interlocking) antar partikel tinggi dan proses tersebut semakin meningkat seiring bertambahnya campuran semen dan fly ash. Selain itu, membuat rongga-ronga pori sampel yang sudah ada sebagian akan dikelilingi bahan tersementasi yang lebih keras, membuat butiran tidak mudah berubah bentuk dan hancur (Husnah et al., 2019).

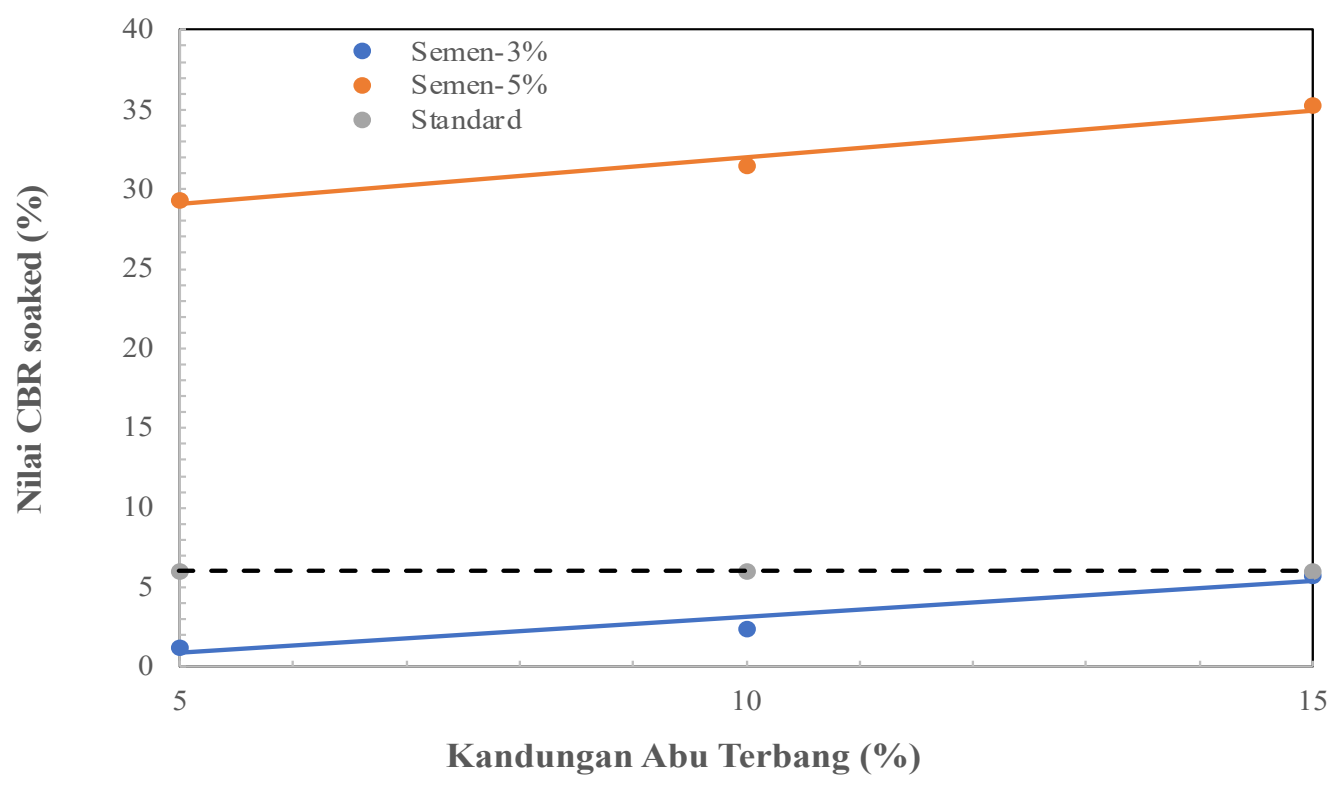

Gambar 1. Harga CBR Campuran Curing 7 Hari

Merujuk Gambar 1, penambahan campuran semen sebanyak 3\% dan abu terbang sampai dengan $15 \%$ tidak mampu menaikan nilai CBR rendaman sampai dengan $6 \%$. Syarat material bisa digunakan sebagai bahan sub-grade perkerasan jalan, nilai CBR rendaman (soaked) harus lebih tinggi dari 6\% (lihat Tabel 4).

Untuk penambahan semen sebesar 5\%, penambahan abu terbang dari 5\% sampai dengan $15 \%$ menambah nilai CBR rendaman menjadi $29,33 \%$ sampai dengan $35,23 \%$. Nilai ini jauh lebih tinggi dari standar material yang bisa digunakan sebagai sub-grade tanpa perbaikan $\tan a h(>6 \%)$

Melihat trend kurva pada Gambar 1, penambahan kadar abu terbang dengan kelipatan 5 $(5 \%, 10 \%, 15 \%)$ membentuk garis linier. Jadi kenaikan nilai CBR soaked, baik untuk kadar semen 3\% maupun 5\% adalah konstan. Gradient kenaikan nilai CBR sekitar 0,5 (0,45 sampai dengan 0,55 ) dari abu terbang yang ditambahkan.

Gambar 2 merupakan hubungan antara kadar abu terbang dengan kepadatan kering (g dry) dan nilai CBR soaked. Stabilisasi material dengan semen, bisa digunakan sebagai bahan lapis fondasi (sub-base, base) tergantung dari nilai CBR rendaman yang diperoleh. Sub-base merupakan lapisan fondasi bawah yang menerima beban kendaraan paling kecil, harus memiliki nilai CBR (kondisi curing 7 hari, dan rendaman 4 hari) lebih besar dari $20 \%$. 

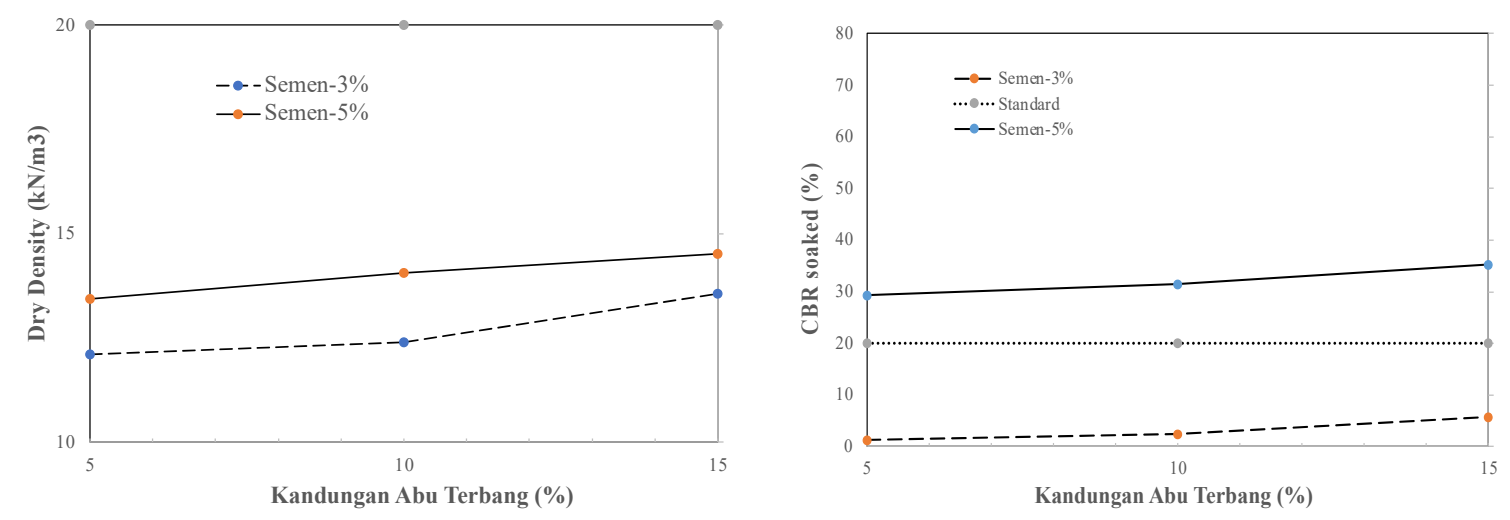

Gambar 2. Berat Volume Kering Tanah Asli dan Campuran

Hasil yang diperoleh menujukkan peningkatan nilai $\gamma$ dry dari sampel dengan kadar FA rendah menuju kadar tertinggi.

\section{KESIMPULAN DAN SARAN}

Penggunaan semen sebesar 3\% sampai dengan 5\% dan abu terbang sebesar 5\% sampai dengan $15 \%$, merubah lempung plastisitas tinggi menjadi lanau dengan plastisitas tinggi. Panas hidrasi sebagai hasil reaksi antara mineral lempung dengan semen dan abu terbang menyerap air.

Stabilisasi lempung plastisitas tinggi dengan semen 5\% dan abu terbang (5\%-15\%) bisa digunakan sebagai lapis tanah dasar (sub-grade) perkerasan jalan raya.

Penambahan semen 5\% dan abu terbang 10\%-15\% dengan pemeraman minimal 7 hari dan direndam 4 hari bisa digunakan sebagai lapis fondasi bawah (sub-base) atau material timbunan lereng perkerasan jalan raya.

Saran untuk penelitian selanjutnya, yaitu:

1. perlu membandingkan efektifitas stabilisasi dengan semen dan stabilisasi menggunakan abu terbang sampai kadar $15 \%$.

2. Pengujian CBR lebih divariasikan lama pemeraman menjadi $0,3,7,14$, dan 28 hari serta diuji pada kondisi tanpa rendaman dan rendaman.

3. perlu pengujian kuat geser campuran, permeabilitas campuran serta elastisitas campuran untuk melihat sifat material campuran

\section{DAFTAR PUSTAKA}

Agung, I. G., \& Istri, A. Y. U. (2014). Studi Kasus di Desa Tanah Awu, Lombok Tengah.

Andriani, A., Yuliet, R., \& Fernandez, F. L. (2012). Pengaruh Penggunaan Semen Sebagai Bahan Stabilisasi Pada Tanah Lempung Daerah Lambung Bukit Terhadap Nilai Cbr Tanah. Jurnal Rekayasa Sipil (JRS-Unand), 8(1), 29. https://doi.org/10.25077/jrs.8.1.29-44.2012

Arifin, B. (2009). Penggunaan Abu Batu Bara PLTU Mpanau Sebagai Bahan Stabilisasi Tanah Lempung. SMARTek, $7(4), 219-228$.

Chen, F. H. (2012). Foundation on Expansive Soils: Developments in Geotechnical Engineering(12th ed.). Elsevier Ltd.

Chiang, P.C. and Pan, S.Y., 2017. (2017). Fly Ash, Bottom Ash, and Dust (pp. 253-264). Springer, Singapore. Springer-Carbon Dioxide Mineralization and Utilization, 253-264.

Chindaprasirt, P., Chareerat, T., Hatanaka, S., \& Cao, T. (2011). High-Strength Geopolymer Using 
Fine High-Calcium Fly Ash. Journal of Materials in Civil Engineering, 23(3), 264-270.

Cokca, E., \& Yilmaz, Z. (2004). Use of Rubber and Bentonite Added Fly Ash as a Liner Material. Waste Management, 24(2), 153-164.

Damoerin, D. and Soepandji, B. S. (2001). Tanah dan Permasalahannya Sebagai Subgrade, "Pemeliharaan Jalan dan Jembatan"(10.1088/1757-899X/615/1/012120.).

Darmawan, W., Rachmansyah, A., \& Zaika, Y. (2018). Perubahan Stabilitas Tanah Akibat Penambahan Kapur, Semen, dan Fly Ash pada Tanah Lunak Proyek Tol Gempol-Pasuruan. JOM Jurusan Teknik Sipil UB, 1(2), 993-1004.

Das, B. M., Endah, N., \& Mochtar, I. B. (1995). Mekanika Tanah Jilid 1 (Prinsip-prinsip Rekayasa Geoteknis). In Erlangga.

Deepak, M. S., Rohini, S., Harini, B. S., \& Ananthi, G. B. G. (2020). Influence of fly-ash on the engineering characteristics of stabilised clay soil. Materials Today: Proceedings. https://doi.org/10.1016/j.matpr.2020.07.497

Endang Widorowati Hartosukma. (2005). Perilaku Tanah Lempung Ekspansif Karangawen Demak Akibat Penambahan Semen dan Fly Ash Sebagai Stabilizing Agents. Universitas Diponegoro.

Forsman J, Jyrävä H, Lahtinen P, Niemelin T, H. I. (2015). Mass Stabilisation Handbook.

Hardiyatmo, H. C. (2010). Stabilisasi Tanah untuk Perkerasan Jalan. In Stabilisasi Tanah untuk Perkerasan Jalan. Universitas Gajah Mada.

Hower, J.C., Groppo, J.G., Henke, K.R., Graham, U.M., H., \& M.M., Joshi, P., and Preda, D.V., 2017. (2017). Ponded and landfilled fly ash as a source of rare earth elements from a Kentucky power plant. Coal Combustion and Gasification Products, 9, 1-21.

Huri, A. D., Yulianto, K., R W, S. P., \& Hardiyati, S. (1989). Stabilisasi Tanah dengan Fly Ash dan Semen untuk Badan Jalan PLTU Asam-Asam. 1-8.

Husnah, Darfia, N. E., \& Prayino, S. E. (2019). Stabilisasi Tanah Lempung Dengan Campuran Semen dan Fly Ash. RACIC, 4(1), 32-41.

Ilyas, T., Rahayu, W. and Arifin, S. (2008). Studi perilaku kekuatan tanah gambut Kalimantan yang distabilisasi dengan semen Portland. Jurnal Teknologi, 1(1), 1-8.

Ingles, O.G. and Metcalf, J.B. (1972). (1972). Soil Stabilization. Butterworth pty, Ltd.

Kosnatha, S., \& Utomo, J. P. (2007). Komposisi dan Karakteristik Beton Geopolimer dari Fly Ash Tipe C dan Tipe F. Universitas Kristen Petra.

Lembasi, M. K., Nugroho, S. A., \& Fatnanta, F. (2021). Pengaruh Waktu Curing Terhadap Nilai Swelling Pada Tanah Lempung Dengan Campuran Fly Ash Dan Bottom Ash. Dinamika Rekayasa, 17(1), 56-65.

Loya, M. I. M., \& Rawani, A. M. (2014). Strategic Framework for Commercialisation of Fly Ash Innovations. Technology Analysis \& Strategic Management, 28(5), 555-567.

Nugroho, S. A., Fatnanta, F., \& Alridho, M. F. (2021). Effect of Adding Wood Powder Ash on CBR Value in Stabilized High Plasticity Clay Cement and Lime. ASTONJADRO, 1O(2), 301-307.

Nugroho, S. A., Ningrum, P., \& Muhardi. (2020). Pemanfaatan Geopolimer Abu Terbang Sebagai Pozzolanic Tanah Lempung Untuk Material Tanah Dasar Perkerasan. Jurnal Fondasi, 9(1), 7786.

Nugroho, S. A., Suratman, \& Pratama, D. (2017). Kajian Rentang Kadar Air Terhadap Nilai Kuat Geser Perbaikan Sirtu Dengan Metode CTB. KoNTekS 11, October, 47-54.

Pandian, N.S., 2013. (2013). Fly Ash Characterization with Reference to Geotechnical Applications. Journal of the Indian Institue of Science, 84(6), 189-197.

Ram, L.C. and Masto, R. E. (2014). Fly ash for soil amelioration: a Review on the I of Ash Blending with Inorganic and Organic Amendments. Earth-Science Reviews, 128, 52-74.

S. Kolias, V. Kasselouri-Rigopoulou, A. K. (2005). Stabilisation of clayey soils with high calcium fly ash and cement. Cement and Concrete Composites, 27(2), 301-313.

Soekoto, I. (1984). Mempersiapkan Lapis Dasar Konstruksi. Badan Penerbit Pekerjaan Umum.

Susanto, D., Djauhari, Z., Olivia, M. (2019). Karakteristik Beton Portland Composite Cement (PCC) dan Silica Flume Untuk Aplikasi Struktur di Daerah Laut. Jurnal Rekayasa Sipil (JRS-Unand), 15(1), 1-11.

Wang, S. and Wu, H. (2006). Environmental-benign Utilisation of Fly Ash as Low-Cost Adsorbents. Journal of Hazardous Materials, 136(3), 482-501.

Zulnasari, A., Nugroho, S. A., \& Fatnanta, F. (2021). Perubahan Nilai Kuat Tekan Lempung Lunak Distabilisasi Dengan Kapur dan Limbah Pembakaran Batubara. Jurnal Rekayasa Sipil (JRSUnand), 17(1), 24. https://doi.org/10.25077/jrs.17.1.24-36.2021 